\title{
The Pandemic in the Middle East and North Africa: Reflections on Current and Future Impacts
}

\section{Petra Weyland}

George C. Marshall European Center for Security Studies, https://www.marshallcenter.org

\begin{abstract}
Covid-19 has spared no region of the world's Global South and Global North. For obvious reasons, countries in the Global South are especially hard hit. This includes MENA, as most of its countries and societies belong to the Global South. The outcomes of perennial poverty, authoritarianism, corruption, and other serious long-term deficiencies mean that this virus hit societies extremely ill-prepared to mobilize the tremendous efforts needed to counter not only the immediate but also the immense future challenges. As long-term governance deficiencies and the new challenges emanating from COVID-19 are mutually reinforcing each other, finding and implementing sustainable solutions for the future becomes even more difficult - and more urgently needed. This prospect cannot remain without implications for the whole Mediterranean region - and for Europe. European-MENA partnerships are more needed than ever. In order to be effective, these partnerships need to include many new stakeholders; they need to be based on trust and on the principle that responsibility for regional, national, and especially for human security has to be shared.
\end{abstract}

Keywords: MENA, COVID-19, governance, international aid, EuropeanMENA partnerships.

\section{Introduction ${ }^{1}$}

There is hardly any country in the world which has not been hit hard by the COVID-19 pandemic. The situation in the US or South Korea shows that even the most affluent and stable countries in the Global North have not been spared,

1 My thanks go to Rocio Corrales Rayon for her valuable comments on this article. 
and are fighting to keep their populations safe and their economies functioning. If it is extremely challenging for the Global North to control the pandemic, countries in the Global South face an excruciating uphill struggle. Perennial poverty, poor governance, and structural deficiencies mean that most countries in the Global South are incapable of successfully meeting a crisis of the COVID-19 dimensions without sustained external assistance. Not only are effective social systems largely non-existent in the least developed countries, but national economies are also extremely weak. Moreover, governing elites are, more often than not, populist, authoritarian, and corrupt - all of which is standing in the way of successfully addressing this enormous challenge.

A quick look at available statistical data and research ${ }^{2}$ shows that most countries in the Middle East and North Africa (MENA) are no exception in this regard. Insightful in this respect is the 2019 Fragile State Index, ${ }^{3}$ which characterized them as "highly fragile" and placed the majority ${ }^{4}$ of them in the "warning" or the "alert" category. The Arab Multidimensional Poverty Report 5 "reveals that across the 286 million people living in the ten countries covered in this analysis, 116.1 million (40.6\%) belong to poor households, of which 38.2 million (13.4\%) live in acute poverty." Another important document, compiled by the United Nation's Economic and Social Commission for Western Asia (ESCWA), provides clear indicators for the numerous severe structural deficiencies. It highlights that "Poverty is widespread, affecting more than four in ten households and children," and that "An additional quarter of the population is vulnerable to household poverty and the majority of the poor in LDCs [among the Arab countries] are severely poor." 6

All these reports show that the prerequisites to successfully addressing a pandemic of the COVID-19 dimensions, and especially its long-term fallout, are hardly given in the MENA region. Coping with the immediate effects of the pandemic necessitates functioning national and local government administrations and critical infrastructure, funds, and capacities enabling them to provide the

2 See, for example: UNDP, Arab Human Development Reports (AHDR), http://arabhdr.org; Joseph Bahout et al., Arab Horizons: Pitfalls and Pathways to Renewal (Washington, DC: Carnegie Endowment for International Peace, 2018), https://carnegie endowment.org/files/ArabHorizons_report_final.pdf; Adel Abdellatif and Ellen Hsu, UNDP's Regional Bureau for Arab States, “Grappling with a Crisis Like No Other: The Fragility of Arab Countries in the Face of COVID-19," Medium.com, March 31, 2020, https://medium.com/@UNDPArabStates/grappling-with-a-crisis-like-no-other-thefragility-of-arab-countries-in-the-face-of-COVID-19-a174b1017824.

32019 Fragile State Index, https://fragilestatesindex.org.

4 The exceptions being some Gulf countries like Oman, UAE, or Qatar.

5 United Nations Economic and Social Commission for Western Asia, Arab Multidimensional Poverty Report, No. E/ESCWA/EDID/2017/2; (Beirut: United Nations, 2017), p. 7, https://www.unescwa.org/sites/www.unescwa.org/files/publications/files/ multidimensional-arab-poverty-report-english.pdf.

6 UN Economic and Social Commission for Western Asia, Arab Multidimensional Poverty Report, p. 21. 
necessary public services, a well-equipped health system at the disposal of all societal strata, a social system providing for people in need, and a healthy economy. In other words, the precondition for successfully fighting the pandemic is a high degree of national and human security - which is largely absent in the region.

This article provides a closer look at the deep-rooted politico-economic deficiencies standing in the way of successfully addressing the pandemic's immediate and future consequences for human and national security in the MENA region. Factoring in these historical, structural shortcomings will be a condition sine qua non for any successful strategy to mitigate the long-term fallout of the pandemic. With security in the region already at an all-time low, there is a high risk of even more instability and crises as a long-term effect of the pandemic. This cannot remain without implications for MENA's neighbor - Europe. It is, therefore, in Europe's best interest to provide strategically informed support. Immediate cash assistance where needed is, most certainly, the immediate task. Yet, any mid- and long-term collaboration to overcome the effects of the pandemic needs to be built on the profound analysis outlined in this article.

\section{COVID-19 Hits a Region Plagued with Perennial Structural Deficiencies}

At the time of writing, it is too early to develop a full picture of the dimensions of the pandemic's long-term fallout. What is clear, however, is that the region was in dire need of reform long before the outbreak of COVID-19, and these structural shortcomings make it impossible to address the crisis meaningfully today. The fallout of the pandemic will be one more heavy burden, ${ }^{7}$ compounding and reinforcing the enormous socio-economic, fiscal, societal and cultural grievances the region has been plagued with for so long. ${ }^{8}$ The future does not bode well for MENA's regional, national, and human security, which cannot remain without consequences for the entire Mediterranean region.

Long-term unresolved ailments will continue to haunt the region. Except for the Gulf region, MENA countries have been hard hit by decades of neo-liberal reforms of the post-independence state-led economies. Structural adjustment and privatization of state economies, continuous reduction of social services, increasing authoritarianism and expanding security sectors, coupled with crony capitalism, a dramatically growing population, and a skewed demographic pyra-

7 Marwan Muasher, "The Old Ways Won't Work," Diwan - Middle East Insights from Carnegie, April 9, 2020, https://carnegie-mec.org/diwan/81478.

8 Marwan Muasher, "The Next Arab Uprising. The Collapse of Authoritarianism in the Middle East," Foreign Affairs (November/December 2018), www.foreignaffairs.com/ articles/middle-east/2018-10-15/next-arab-uprising; Rami G. Khouri, "Comprehensive, Contentious, Convulsive, and Continuing: Some Observations on the 2010-2020 Arab Uprisings," Journal of Middle East Politics and Policy (A Harvard Kennedy School student publication, Spring 2020): 8-14, https://jmepp.hkspublications.org/wpcontent/uploads/sites/17/2020/03/Khouri.pdf. 
mid has led to an ever-increasing poor stratum, a shrinking middle class and the emergence of a minority of super-rich. All of this has had extremely detrimental effects not only for citizens but also for state-society relations, for the stability of the MENA region as a whole, and even for Europe as a major migrant destination. Long gone are the times of the post-independence era when social contracts between the populist revolutionary political leaders of countries like Egypt, Iraq or Tunisia successfully traded social services with political acquiescence. Gone are the days when generous funds from the Gulf states provided an alternative source of finance to poor Arab neighbor states. Irrevocably gone are the days when the precarious population found an alternative for diminishing state subsidies by becoming labor migrants in the oil-producing Gulf states. Though still much better off, with sharply declining oil revenues since 2014 and with no viable alternative to the rentier system in place, the situation has become precarious even in the Gulf states. For decades, the extreme wealth generated in the oil sector allowed the ruling elite to trade abstention from politics and any critique of the royal elites for the affluent lifestyle of the indigenous Arab population. As the end of the oil economy grows nearer, the oil price on global markets has plummeted to an all-time low, and no alternative strategies for a sustainable future have been implemented. Consequently, dark clouds were already gathering on the horizon of the formerly extremely rich Gulf countries before the outbreak of the pandemic.

The major deficit in all MENA countries-poor or rich-is the same. For decades, the heirs of the post-independence populist and secular political leaders (and also the royal families) have turned out to be unable to implement feasible solutions to the socio-economic quagmire sketched above. Primarily interested in warding off any threats to their privileged political and economic status arising from the increasingly disenfranchised masses, they have molded governance into ever more authoritarian and corrupt administrations and invested heavily into expanding their country's security sectors, making sure that these primarily serve the interests of elites and bureaucracies, instead of seriously addressing the needs for the safety and security of their societies.

Growing popular frustration with the increasingly untenable situation came to a head in 2011 with the Arab uprisings' demands for dignity, bread, and the fall of the regimes. Some ruling elites-especially in the kingdoms of Morocco, Jordan, and Saudi Arabia-quickly reacted and met some of their population's most urgent needs. Tunisia made courageous steps towards addressing the demands of Tunisian men and women. These measures, however, proved to be largely insufficient. The other authoritarian elites in MENA countered the populist demands voiced in 2011 with even more repression, hence the total devastation we see today in Syria, Iraq, Yemen, and Libya. Yet, even under the repressive circumstances of today, which are much more dire than in 2011, popular protest has been rising again in many MENA countries - most prominently in Iraq, Lebanon, Jordan, Sudan, Algeria, and Tunisia. 
This was, by and large, the politico-economic landscape in MENA when the COVID-19 crisis hit: large parts of the region are embroiled in endless, extreme, armed violence; next to nothing had been achieved with regard to new social contracts balancing the legitimate human security needs of the populace with the need for regime stability, ${ }^{9}$ economies still plummeting, and a culture of fear and immense reciprocal distrust determining the relationships between political elites and the Arab populace. In short, when COVID-19 hit, national and human security, freedom from fear and freedom from want, were already at an all-time low, with many thousands of citizens in the conflict zones dead, maimed, or suffering from PTSD, with further thousands incarcerated for demanding reforms, and with the young people turned into a lost generation, unable to play their natural role in becoming capable and qualified future leaders of their countries.

Not to be forgotten are the hundreds of thousands of men, women, and children who tried to find an individual path out of their predicament by becoming internally displaced persons (IDPs) in their own countries or as refugees populating over-crowded camps in Lebanon, Jordan or Turkey. Nor does the future bode well for those refugees who went even further away from their countries and ended up vegetating in EU hotspots such as the Greek islands. ${ }^{10}$ Their fate was already extremely bleak before the pandemic. The local host populations, over time, turned from an initially welcoming attitude to becoming increasingly hostile - either because the local governance infrastructure was not built to accommodate the endless number of migrants, or because of a generally growing populism and anti-refugee agitation. Adding to their predicament is the inability, or unwillingness, of Europe, whether nationally or collectively, to implement durable solutions for these people. Living in extremely densely populated areas, which makes physical distancing impossible, and suffering from a shortage in water, hygiene, and sanitation, ${ }^{11}$ asylum seekers, refugees, and IDPs are among the segments of the MENA population most at risk to be infected by the coronavirus.

In short, all these societal long-term deficiencies make any endeavor to successfully address the pandemic a highly challenging enterprise. What is more, many authoritarian elites are already using measures to restrict the spread of the pandemic to consolidate further their own power positions to the detriment

9 Thus, the Bertelsmann Transformation Index (BTI) for 2020 states about the MENA region: "There is barely a single country that is truly addressing its fundamental structural problems: elite power circles and widespread corruption; population growth, particularly among the poorest sectors; and the fragility of overall security," https://www.bti-project.org/en/reports/regional-report-ENA.html.

10 Human Rights Watch, "Greece: Refugees Working to Protect Moria Camp from Covid19," April 22, 2020, https://www.hrw.org/hy/node/341138.

11 Justin Schon, "Protecting Refugees in the Middle East from Coronavirus: A Fight against Two Reinforcing Contagions," POMEPS Studies 39, Special Issue on the COVID19 Pandemic in the Middle East and North Africa (Washington, DC: George Washington University, Elliott School of International Affairs, April 2020), http://pomeps.org/protecting-refugees-in-the-middle-east-from-coronavirus-a-fightagainst-two-reinforcing-contagions. 
of their societies. ${ }^{12}$ Struggling with the enormous, long-term burden of the pandemic at home, all countries of the Global North will also have to reassess their ability-and willingness - to provide sufficient assistance. With global commodity chains disrupted, an additional, serious impact will most likely be on the region's food security.

Besides the level of national political economy, the geopolitical dimension is adding yet another layer of complexity to the crisis. Since the invasion of Iraq in 2003, MENA has been witnessing a gradual breakdown of the regional geopolitical order. The US withdrawal has left a space open for a growing number of regional and global actors (especially Iran, Russia, ${ }^{13}$ China, ${ }^{14}$ Turkey, and the Gulf states) to increase their footprints in the region and to support proxy forces or state elites with the aim of changing the geopolitical landscape in their favor.

All these regional and global forces will strive to keep and expand their newly won regional clout. The necessity to divert national funds and capacities to fight the effects of the pandemic in their own countries will not necessarily lead to the withdrawal from the region, but to the search for new mechanisms of retaining influence.

\section{Zeroing in on Nation States and Populations}

While this assessment is generally valid for all countries in the MENA region, the crisis has certainly hit each country in its own different way, disrupting their society, their rural and urban areas, their individual citizens, or their households. Also, as the crisis unfolds, each day comes with new developments, new emergencies, and statistical updates - which cannot be covered on these pages. ${ }^{15}$ Yet, it is possible to discern three major categories of countries, and specific segments of the MENA population that are being impacted in particular ways: conflict zones and failed states; relatively stable, economically and structurally very

12 Nathan J. Brown, Intissar Fakir, and Yasmine Farouk, "Here to Stay? The Impact of the Coronavirus in the Middle East Has Led to Shifts in the Nature of Authoritarianism," Diwan - Middle East Insights from Carnegie, April 22, 2020, https://carnegiemec.org/diwan/81611; Sarah Yerkes, "Coronavirus Threatens Freedom in North Africa," Carnegie Endowment for International Peace, April 24, 2020, https://carnegie endowment.org/2020/04/24/coronavirus-threatens-freedom-in-north-africa-pub81625.

13 Dmitri Trenin, "Russia's Viral Calculations," Diwan - Middle East Insights from Carnegie, April 16, 2020, https://carnegie-mec.org/diwan/81575.

14 Guy Burton, "China and COVID-19 in MENA," POMEPS Studies 39, Special Issue on the COVID-19 Pandemic in the Middle East and North Africa (Washington, DC: George Washington University, Elliott School of International Affairs, April 2020): 25-28, https://pomeps.org/china-and-covid-19-in-mena.

15 For a daily update on COVID-19 in the Middle East, the BBC Essential Media Insight Service may be consulted at https://monitoring.bbc.co.uk. 
fragile countries; and lastly, the Arab oil-exporting countries in the Gulf region. ${ }^{16}$ Going beyond the macro level of nation states and including the micro-level of the pandemic's implications for individuals and households is also necessary as these are the basic element of any society. Turning a blind eye to the pandemic's impact on the microcosm of everyday life would miss an analysis of the repercussion on the macro-level of a nation state and its stability.

Firstly, there are the conflict zones and failed states - countries like Libya, Yemen, Iraq, and Syria, all of which have been embroiled in years of civil wars and armed conflicts as an aftermath of the Arab uprisings in 2011. Years of protracted conflict have resulted in an almost completely destroyed infrastructure of public and social services; countries split into hybrid and dynamic constellations of competing state, non-state, para-state and foreign actors fighting with or against what was once a central government; economies in ruins; the young generation (the future of any society) without proper education, excluded from participation in the decision making of their country or having left the country. This category also includes the overpopulated Gaza Strip ${ }^{17}$ under Israeli blockade. Civilians living in conflict zones and failed states are hit hardest by the crisis. ${ }^{18}$

Then, there are the relatively stable yet fragile countries. Lebanon, Jordan, Egypt, Algeria, and Tunisia fall into this category. With their large populations and weak administrations, each of them is struggling with its own particular structural weaknesses. Though existing government and administration structures provide basic services to fight the current impact of the pandemic, without desperately needed assistance from the global community these countries will soon face extremely high challenges if they are not to slip from fragility into breakdown. This is all the more important as financial assistance from Gulf countries has sharply diminished due to plummeting oil prices. Adding to the fragility of these countries is the fact that the population, and especially the young generation, is largely excluded from political decision-making and sees no future in their countries. While outside observers tend to think that the 2011 Arab uprisings were no more than a short-lived "Arab Spring," the generation of the uprisings actually has continued to voice its grievances, its demands for economic opportunities, and for inclusion and accountability. Learning from past mistakes,

16 For an analysis of individual countries, see: POMEPS Studies 39, a special issue on the COVID-19 Pandemic in the Middle East and North Africa, April 2020: https://pomeps.org/wp-content/uploads/2020/04/POMEPS_Studies_39_Web.pdf.

17 Zaha Hassan and Hallaamal Keir, "U.S. Policy Response to Coronavirus in Gaza," Policy Outlook - Carnegie Endowment of International Peace, March 30, 2020, https://carnegieendowment.org/2020/03/30/u.s.-policy-response-to-coronavirus-ingaza-pub-81390.

18 Eric Goldstein and Amy Braunschweiger, "When Health Care Is Decimated By War: COVID-19 in the Middle East and North Africa," Human Rights Watch, April 16, 2020, accessed April 20, 2020, https://www.hrw.org/news/2020/04/16/when-health-caredecimated-war-COVID-19-middle-east-and-north-africa. 
the protesters have developed new networks and new forms of action to make their demands heard.

Sharply declining revenues from the oil and the tourism sectors have made it difficult even for the rich oil-exporting countries to implement the necessary coping strategies for the basic politico-economic challenges. Rich oil revenues allowed the maintenance of an excellent health system in the past, which has enabled Gulf States' administrations today to meet the immediate COVID-19 challenges of their inhabitants successfully. This is, however, not the case for a large number of the Gulf population - the labor migrants, including migrant domestic labor. Again, the situation is exacerbated by the particular challenges each individual country is facing, ${ }^{19}$ for example, the high cost of Saudi Arabia's war in Yemen and the loss of revenue from the Hajj pilgrimage.

It should not be forgotten that the crisis is deeply affecting the safety and security of each individual male and female citizen, of each household and of many local communities. The urgency of addressing their needs, especially in these times, is not only a matter of human rights but also of the future of their countries. It should be of concern to Europe, too.

The almost complete standstill of all MENA economies most severely affects those at the bottom of the social pyramid. The longer the lockdown continues, the more severely affected are the millions of daily laborers working in the vast informal sectors of their countries. ${ }^{20}$ Prevented from leaving their homes, left without their daily earnings, and without social assistance, they are increasingly unable to bring food to the table-which leaves them with the choice of "death by COVID-19 Virus or death from hunger" - either to ignore quarantine regulations and put themselves at risk of infection and of penalties, or to starve. ${ }^{21}$ Without their meager incomes, and without social services provided by the government, NGOs, non-state actors, armed groups or religious organizations are becoming increasingly important to address the needs of these people. The services that such organizations provide may come at a price, as it gives these organizations the opportunity to gain influence. In the best case, these organiza-

19 See, for example: Netty Idayu Ismail, “Market Devouring Record Gulf Bonds Won't Touch Oman, Bahrain," Bloomberg, April 19, 2020, accessed 20 April,2020, https://www.bloomberg.com/news/articles/2020-04-19/bond-market-devouringrecord-gulf-debt-won-t-touch-oman-bahrain; Vivian Nereim, "Saudi Arabia Looks at 'Painful Measures,' Deep Spending Cuts," Bloomberg, May 2, 2020, www.bloom berg.com/news/articles/2020-05-02/saudi-arabia-looking-at-painful-measures-deepspending-cuts.

20 For a definition of the informal sector and statistical data from 1999-2007, see Friedrich Schneider, Andreas Buehn, and Claudio E. Montenegro, "Shadow Economies: All over the World: New Estimates for 162 Countries from 1999 to 2007," Policy Research Working Paper No. 5356 (The World Bank, July 2010), http://documents.world bank.org/curated/en/311991468037132740/pdf/WPS5356.pdf.

21 Rana Taha and Dina Aboughazala, "COVID-19 Analysis: Can Arab World's Poorest Survive Stay at Home Calls?" Insight BBC Monitoring, April 13, 2020. 
tions eventually will be incorporated into trustful local governance structures. In the worst case, aid is conditional on their joining an armed group.

Continued lockdowns and quarantines, rising numbers of deaths, the impossibility to make ends meet has already resulted in severe psychological, emotional, physical, and sexual impacts on most MENA citizens, especially on those living in overcrowded housing conditions in slum areas, or in refugee camps. Among the most vulnerable groups are children and women, IDPs, refugees and labor migrants, ${ }^{22}$ including live-in domestic labor. Domestic violence is sharply increasing in all societies hit by the Coronavirus, yet these groups are especially vulnerable. Lockdowns have made evading domestic violence even more precarious because institutions which in normal times assist victims, like women's shelters, have also been forced to reduce their services drastically. Also, seeking support from the police or from the judiciary has become almost impossible. A recent report ${ }^{23}$ gives some examples of domestic violence in Lebanon. It can be expected to be similar in all societies of the region, and beyond.

Another especially vulnerable group about which next to nothing is heard are the hundreds of thousands of IDPs in war zones. The closure of internal borders is an enormous additional challenge for government services or for international organizations to provide assistance. Like IDPs, the local rural population is highly depending on local voluntary organizations that are trying to do their best even though they are ill-equipped and underfunded. As mentioned before, the dire situation might leave people with no other choice than to seek help from some paramilitary group, which then might force them to become active supporters of a violent extremist group.

In trying to understand the human suffering caused by COVID-19, we cannot forget the refugees and asylum seekers in the dramatically overcrowded camps in Greece ${ }^{24}$ or the fate of those being pushed around in Turkey - many of them from the conflict zones in MENA.

\section{Regional and International Assistance}

In short, national government administrations are hardly able to sufficiently address and mitigate the effects of coronavirus in their countries. The situation is aggravated by the fact that coordinated Arab national responses to address the pandemic on the regional level are absent in MENA. Furthermore, regional bodies - the Arab League, the Organization of Islamic countries, or the Gulf Cooper-

22 Mauro Testaverde, "Social Protection for Migrants during the COVID-19 Crisis: The Right and Smart Choice," World Bank Blogs, April 28, 2020, https://blogs.world bank.org/voices/social-protection-migrants-during-covid-19-crisis-right-and-smartchoice.

23 Hesham Shawish, "Covid 19 Analysis: Lockdown Shines Light on Domestic Abuse in Lebanon," BBC Monitoring: Insight, April 15, 2020, accessed April 16, 2020.

24 Human Rights Watch, "Greece: Island Camps Not Prepared for Covid-19-Government Neglect Puts Lives at Risk," April 22, 2020, https://www.hrw.org/news/2020/04/ 22/greece-island-camps-not-prepared-COVID-19. 
ation Council, ${ }^{25}$ are traditionally very weak and, therefore, of little, if any, help in the current situation.

As countries in the Global North are likewise under enormous pressure to make their economies survive, the amount of intergovernmental aid from the Global North might be slowing down for a number of reasons, among them the pandemic induced severe global economic downturn. So, the future is not bright. Growing populism and unilateralism also have a negative impact on international solidarity, recent examples being the President of the United States' decision to cease financing the WHO, or most European countries' refusal to accommodate even small numbers of unaccompanied minors living in the hotspots on Greek islands.

International and multilateral organizations, such as the IMF, WHO, G7 or the $E U$, are aware of the situation and are considering assistance. Yet the enormous amount of assistance needed worldwide makes it difficult for even these bodies to provide the necessary help.

\section{Wrapping up: Challenges of the Future}

Successfully addressing a pandemic of the COVID-19 dimensions is not only dependent on funding, on capable technocrats taking the lead in fighting the pandemic, and on a reasonably functioning administration. Ultimately, recovery depends upon accountability, transparency, and trust, and on the participation and inclusivity of citizens - all under the umbrella of a vision of shared responsibility. Essential to this is the buy-in of the population, and the political leadership genuinely putting the country's wellbeing first. These are the preconditions for MENA countries to successfully navigate the dire straits of recovery once the virus has been defeated. In other words: without a meaningful new social contract in place, no administration, no ruling elite, can successfully combat the longterm effects of the pandemic. If all this was lacking even before the outbreak of the crisis, it is hard to foresee how an already extremely worn out population can shoulder the additional hardships necessary for the recovery of their country. ${ }^{26}$ And yet, without these conditions being met, the region will almost certainly descend into even more destabilization.

Even if all these preconditions were to be met, the region would still need the solidarity of external partners with a genuine interest in peaceful, thriving neighbors. The first addressee in this respect certainly is Europe. What is needed is that the EU operationalizes its values, goals, and actions, as defined in the Global

25 See, however, for assistance to address the immediate needs of the fight against the pandemic: Matthew Hedges, "Authoritarian Exploitation of COVID-19 in the GCC," POMEPS Studies 39, 35-37.

26 Muasher, "The Old Ways Won't Work." 
Strategy for the European Union's Foreign and Security Policy ${ }^{27}$ into powerful forms of sustained engagement.

These are the preconditions to master the future fallout of the pandemic. These are also the preconditions for the region to address another looming crisis of even larger dimensions than COVID-19: the effects of climate change.

\section{Disclaimer}

The views expressed are solely those of the author and do not represent official views of the PfP Consortium of Defense Academies and Security Studies Institutes, participating organizations, or the Consortium's editors.

\section{Acknowledgment}

Connections: The Quarterly Journal, Vol. 19, 2020 is supported by the United States government.

\section{About the Author}

Petra Weyland studied Islamic Sciences in Bonn, Germany. She received her PhD degree in Social Anthropology of Middle Eastern Societies from Bielefeld University, Germany. She derives her expertise from many field studies in the region, from teaching at the General Staff Academy of the German Armed Forces, and the George C. Marshall European Center for Security Studies. Among her major research interests are the human dimensions of security and innovative approaches to security in the Mediterranean region.

\footnotetext{
27 "Shared Vision, Common Action: A Stronger Europe - A Global Strategy for the European Union's Foreign And Security Policy," June 2016, https://eeas.europa.eu/ archives/docs/top_stories/pdf/eugs_review_web.pdf.
} 